\title{
LEPROSY SURVEY OF SCHOOL CHILDREN IN BRITISH GUIANA
}

L. H. Wharton.

It is generally accepted that the incidence of leprosy in children gives a fairly accurate picture of the leprosy problem of that country. In presenting the first report of a general leprosy survey of school children to be made in this Colony it will be necessary to give a short account of the topographical, climatic, sanitary, economic and general health conditions of the Colony, together with racial distribution of its peoples, so that the reader be able to have a comprehensive view of the problem.

The only British possession on the continent of South America Latitude 2-8, British Guiana has an area of 89,000 sq. miles, with a mixed population of approximately 360,000 , giving an area density of 3 persons to the sq. mile. About $45 \%$ of the population is East Indian, 45\% African, and Io $\%$ other races consisting mamly of Portuguese, Chinesc, Aboriginal Indians and Europeans. Approximately $90 \%$ of the population live on the Atlantic coastland of the Colony, in a strip of land 5 miles wide and 280 miles long. The Colony is bordered by Venezeula, Dutch Guiana and Brazil, all countries with a high leprosy incidence, so that there can be no complacency in leprosy control.

The people are mainly agriculturalists although some mining is done. Economically the average person is poor; housing apart 
from the city-Georgetown, New Amsterdam, and the larger villages is poor, and the standard of living and sanitary conditions are poor.

The climate is tropical, with two rainy seasons and two dry seasons a year. Average midday temperature is $80^{\circ} \mathrm{F}$. in the shade, and the average rainfall 70" per annum. The inhabited area of the Colony is low, $4 \mathrm{ft}$. below sea level. A large section of the population suffer fromi secondary anaemia, probably due to malaria, hookworm, and poor diet, which is mainly carbohydrate, with protein content low.

The general School Survey covered the entire coastland, from Skeldon on the border of Dutch Guiana to the North West District on the Venezuelan border. It included all the towns, villages and estates. Several up-river districts with large communities were included. Trained personnel were used,, and a special Survey Card, as recommended by Dr. E. Muir, Medical Secretary, British Empire Leprosy Relief Association, was used for records. The children all attended Government Schools, and drtails of the survey were recorded for each of the three counties of the Colony, and are now presented as such. The time taken for the survey was 18 months, this included school vacations when the survey had to be suspended. The children came from the poorest homes in the Colony. The ages were between one and fourteen years.

\section{TABLE I.}

Carses Extrmened. Number Cases Found.

\begin{tabular}{|c|c|c|c|c|c|c|c|}
\hline District & (iounty & Boys & (iirls & Totai & Boys & Girls & Total \\
\hline Georgetown & Jemerara & 4,491 & 4,795 & 9,280 & 11 & 9 & 20 \\
\hline East Bank: & do. & 1,063 & 932 & 1,995 & 8 & 10 & 18 \\
\hline East Coast & dn. & 4.8 .57 & 4,264 & 9,121 & 8 & 4 & 12 \\
\hline West Coast & do. & !,297 & 1,125 & 2,422 & 3 & - & 3 \\
\hline West Bank & do. & 1,138 & 928 & 2,060 & 1. & 1 & 2 \\
\hline Demerara River & do. & 306 & 303 & 609 & - & 1 & 1 \\
\hline Tuschen-Parika & Essequibo & 247 & 190 & 437 & 1 & 1 & 2 \\
\hline Supernaam-Charit & ty do. & 1,306 & 1,209 & 2,515 & 6 & 2 & 8 \\
\hline Leguan & do. & 464 & 354 & 818 & - & 1 & 1 \\
\hline Wakenaam & do. & 356 & 348 & 704 & - & - & - \\
\hline Bartica & do. & 167 & 179 & 346 & - & 1 & 1 \\
\hline New Amsterdam & Berbice & 741 & 756 & 1,496 & 1 & 3 & 4 \\
\hline Fast Bank & do. & 267 & 217 & 484 & - & 1 & 1 \\
\hline Canje & do. & 659 & 591 & 1,250 & 1 & 2 & 3 \\
\hline Corentyne & do. & 3,815 & 2,859 & 6,674 & 7 & 8 & 15 \\
\hline West Coast & do. & 1,187 & 1,295 & 2,482 & 1 & 2 & 3 \\
\hline Morawhana & North West & $t 30$ & 35 & 65 & - & - & - \\
\hline Mabaruma & do. & 21 & 19 & 40 & - & - & \\
\hline TOTAL & & 2,412 & 20,399 & 42,811 & 48 & 46 & 94 \\
\hline
\end{tabular}

The number of boys infected was 48 , number of girls 46 . This is unusual as the rate of male to female is in most countries 
2 to I. It will be seen that most of the cases were in the 6-Io age group. The number of Africans infected was $5^{8}$ against 36 Indians.

It will be seen that of 42,8 I I children examined 94 cases were found. With the exception of 3 cases all the children, who had early neural lesions, were treated at clinics as outpatients, and allowed to continue at school. The 3 cases referred to, I lepromatous and 2 more advanced neural, were admitted to the Leprosy Hospital Children's Homes.

The incidence is shown in Table II.

TABLE II.

\begin{tabular}{lllcccc}
\multicolumn{1}{r}{$\begin{array}{c}\text { County } \\
\text { J'emerara }\end{array}$} & & & Boys & (iirls & Total & Per Mille \\
Berlice $\ldots$ & $\ldots$ & $\ldots$ & 31 & 25 & 56 & 2.2 \\
Fsseguibo & $\ldots$ & $\ldots$ & 7 & 5 & 12 & 2.1 \\
North West & $\ldots$ & $\ldots$ & 10 & 16 & 26 & 2.4 \\
\cline { 3 - 7 } & & $\ldots$ & - & - & - & - \\
\cline { 3 - 7 }
\end{tabular}

The lower East Bank Demerara River was the area showing the largest incidence 9 per $\mathrm{I}, 000$. This incidence is so high as to warrant a house to house survey from La Penitence to Meadow Bank, inclusive, if trained personnel can be made available.

An attempt has been made in Georgetown to examine contacts, by the Govt. Medical Officer of Health of Demerara. Owing to lack of trained personnel we have been unable to carry out house examinations in the homes of infected children, although child contacts from infected homes were examined at the clinics.

In the course of the survey we were able to recommend many children suffering from yaws, scabies, ringworm, hookworm; malaria, lice, and avitaminosis, to District Medical Officers for treatment.

The opportunity was used to spread information on leprosy to the general public, and literature on the subject in the form of booklets and pamphlets was freely distributed. We have made definite progress in convincing the public that the disease can be cured, and the remarkable results obtained in the children treated as outpatients has been proof of this.

We have to record that two teachers were found suffering from Neural Leprosy $\left(\mathrm{N}^{1}\right)$, and reports were sent to the Director of Education.

It is proposed that the School Survey should become a permanent part of the Leprosy Public Health programme and we intend to obtain permission to examine children at secondary and denominational schools at the next survey. 
Conclugions :

(I) It is not possible to make any definite deductions from one survey. Only by repeated surveys will we be able to make comparisons, and say whether the disease is under control or not.

(2) It has brought to light 94 early cases which might not have been seen otherwise, until they were more advanced and difficult to cure.

(3) It has served a most useful purpose in educating the general public in the disease, and gaining their confidence in coming early for treatment. 